\title{
ANALISIS PENEMPATAN PEGAWAI PADA PEMERINTAH PROVINSI DKI JAKARTA
}

\author{
Raden Yudhy Pradityo Setiadiputra \\ Badan Pengembangan Sumber Daya Manusia Provinsi DKI Jakarta \\ Email : raden.pradityo@jakarta.go.id
}

\begin{abstract}
ABSTRAK
Reformasi birokrasi pada hakikatnya merupakan upaya untuk melakukan pembaharuan dan perubahan mendasar terhadap sistem penyelenggaraan pemerintahan terutama menyangkut aspek-aspek kelembagaan (organisasi), ketatalaksanaan (business prosess) dan sumber daya manusia aparatur dan lain sebagainya. Pemerintah Provinsi DKI Jakarta dalam menindaklanjuti pelaksanaan Reformasi Birokrasi telah menerbitkan Peraturan Gubernur Nomor 156 Tahun 2016 tentang Road Map Reformasi Birokrasi Tahun 2015-2017. Salah satu pelaksanaan road map reformasi birokrasi tersebut adalah pada area Sumber Daya Manusia (SDM) yaitu dengan pelaksanaan penempatan Pegawai Negeri Sipil (PNS). Penelitian ini dilakukan untuk menganalisis persepsi pegawai terkait dengan penempatan pegawai di lingkungan Pemerintah Provinsi DKI Jakarta apakah telah sesuai dengan dokumen analisa jabatan dan analisa beban kerja, formasi jabatan serta standar kompetensi jabatan. Metode penelitian yang digunakan pada penelitian ini adalah metode deskriptif dengan pendekatan kualitatif, yang menggunakan teknik pengambilan data kuisioner sederhana yang ditujukan kepada para pegawai di lingkungan Pemerintah Provinsi DKI Jakarta. Hasil penelitian ini dapat disimpulkan bahwa penempatan pegawai di lingkungan Pemerintah Provinsi DKI Jakarta selain mempertimbangkan kebutuhan instansi namun juga telah mempertimbangkan dokumen-dokumen tersebut diatas. Akan tetapi dalam pelaksanaannya, penempatan pegawai masih terdapat banyak kesenjangan, yaitu sebanyak 54,2\% responden menyatakan bahwa dalam penempatan pegawai di instansinya masih terdapat kesenjangan. Sebanyak 93,2\% responden menyatakan bahwa penempatan pegawai pada instansi memiliki peran penting terhadap kinerja instansi/organisasi. Berdasarkan hal tersebut terdapat beberapa faktor lain yang perlu diperhatikan dalam penempatan pegawai di lingkungan Pemerintah Provinsi DKI Jakarta.
\end{abstract}

Kata Kunci: Reformasi Birokrasi, Penempatan Pegawai, Analisa Jabatan, Standar Kompetensi, Kinerja Instansi.

\begin{abstract}
Bureaucratic reform is essentially an attempt to reform and fundamental changes to the system of governance, especially concerning the institutional aspects (organization), management (business processes) and human resources apparatus and so forth. The DKI Jakarta Provincial Government in following up the implementation of Bureaucratic Reform has issued Governor Regulation No. 156 of 2016 concerning the 2015 - 2017. Bureaucracy Reform Road Map. One of the implementation of the bureaucratic reform road map is in the area of Human Resources, namely by the placement of Civil Servants Civil (PNS). This study was conducted to analyze the perceptions of employees related to the placement of employees in the DKI Jakarta Provincial Government whether it is in accordance with the job analysis document and workload analysis, position formation and position competency standards. The research method used in this study is a descriptive method with a qualitative approach, which uses simple questionnaire data collection techniques aimed at employees within the DKI Jakarta Provincial Government. The results of this study can be concluded that the placement of employees within the DKI Jakarta Provincial Government in addition to considering the needs of agencies but also has considered the documents mentioned above. However, in its implementation, the placement of employees still has many gaps, namely as many as $54.2 \%$ of respondents stated that in the placement of employees in their institutions there were still gaps. As many as $93.2 \%$ of respondents stated that the placement of employees in institutions has an important role in the performance of agencies / organizations. Based on this there are several other factors that need to be considered in the placement of employees within the DKI Jakarta Provincial Government.
\end{abstract}

Keywords: Bureaucratic Reform, Employee Placement, Job Analysis, Competency Standards, Institutional Performance. 


\section{PENDAHULUAN}

Reformasi birokrasi merupakan salah satu upaya pemerintah guna menuju good governance. Melihat pengalaman beberapa Negara menunjukkan bahwa reformasi birokrasi merupakan langkah awal untuk mencapai kemajuan sebuah Negara. Melalui reformasi birokrasi, dapat dilakukan penataan terhadap sistem penyelenggaraan pemerintahan yang tidak hanya efektif dan efisien tapi juga reformasi birokrasi menjadi tulang punggung dalam kehidupan berbangsa dan bernegara. Reformasi birokrasi memang harus diterapkan pada seluruh kementerian/lembaga/instansi Pemerintah dan Pemerintah Daerah. Reformasi birokrasi pada hakikatnya merupakan upaya untuk melakukan pembaharuan dan perubahan mendasar terhadap sistem penyelenggaraan pemerintahan terutama menyangkut aspek-aspek kelembagaan (organisasi), ketatalaksanaan (business prosess) dan sumber daya manusia aparatur.

Berdasarkan Peraturan Menteri Negara Pendayagunaan Aparatur Negara dan Reformasi Birokrasi Nomor 9 tahun 2011 Pedoman Penyusunan Road Map Reformasi Birokrasi Kementerian/Lembaga dan Pemerintah Daerah dijelaskan bahwa terdapat 8 (delapan) area perubahan dalam road map reformasi birokrasi di Indonesia. Area perubahan reformasi birokrasi adalah organisasi yang tepat fungsi dan ukuran; sistem proses dan prosedur yang jelas; regulasi yang tertib; sumber daya manusia yang berintegritas; penyelenggaraan Negara yang bebas dari korupsi, kolusi dan nepotisme; meningkatnya kapasitas dan kapabilitas kinerja birokrasi; pelayanan prima sesuai kebutuhan dan harapan masyarakat; serta birokrasi dengan integritas dan kinerja yang tinggi. Berikut dibawah ini disampaikan Gambar 8 Area Perubahan Reformasi Birokrasi.

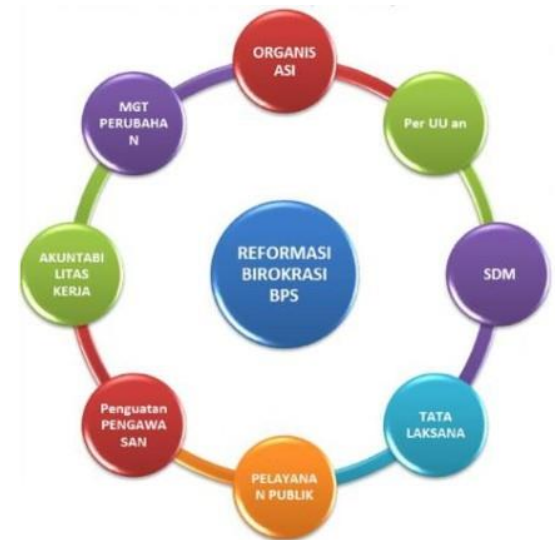

Gambar 1.

8 Area Perubahan Reformasi Birokrasi Sumber : Badan Pusat Statistik
Reformasi birokrasi yang terdapat di Indonesia menempatkan bahwa pentingnya rasionalisasi birokrasi yang menciptakan efesiensi, efektifitas, dan produktifitas dap at melalui pembagian kerja hirarkikal dan horizontal yang seimbang. Hal tersebut dapat diukur dengan rasio antara volume atau beban tugas dengan jumlah sumber daya disertai tata kerja yang bersifat formal dan pengawasan yang ketat. Penataan organisasi setiap instansi pemerintah baik pusat maupun daerah didasarkan pada visi, misi dan sasaran startegis, agenda kebijakan, program dan kinerja kegiatan yang terencana dan diarahkan terbangunannya sosok birokrasi dengan tugas dan bertanggungjawaban terbuka dan aksessif. Pada akhirnya keberhasilan pelaksanaan reformasi birokrasi akan sangat mendukung dalam penciptaan good governance karena reformasi birokrasi merupakan inti dari upaya penciptaan good governance, sehingga akan dapat meningkatkan pelayanan kepada masyarakat dan meningkatkan investasi di Indonesia yang berujung pada peningkatan pertumbuhan perekonomian Indonesia yang membawa implikasi terhadap kesejahteraan rakyat.

Sumber daya manusia (SDM) merupakan salah satu aspek area perubahan reformasi birokrasi khususnya sistem manajemen sumber daya aparatur di lingkungan Pemerintah Daerah. Berdasarkan Pasal 5 Peraturan Pemerintah Nomor 11 Tahun 2017 tentang Manajemen Pegawai Negeri Sipil dijelaskan bahwa Setiap Instansi Pemerintah mempunyai kewajiban menyusun analisis jabatan. Analisa jabatan digunakan dalam memperoleh informasi yang akurat terkait dengan gambaran menyeluruh dan lengkap mengenai suatu posisi jabatan ke dalam format yang memudahkan dalam memahami secara akurat informasi tentang jabatan dalam organisasi serta merancang program dan kegiatan penataan jabatan dan peningkatan kompetensi jabatan.

Analisis jabatan berdasarkan Peraturan Menteri Negara Pendayagunaan Aparatur Negara dan Reformasi Birokrasi Nomor 33 Tahun 2011 tentang Pedoman Analisis Jabatan, merupakan proses dan tata cara untuk memperoleh data jabatan yang diolah menjadi informasi jabatan dan disajikan untuk kepentingan program kelembagaan, ketatalaksanaan, kepegawaian dan pengawasan. Dengan analisis jabatan dapat diperoleh cara yang sistematis yang mampu mengin- 
dentifikasi serta menganalisa persyaratan apa saja diperlukan dalam sebuah pekerjaan serta pegawai apa yang dibutuhkan dalam suatu pekerjaan sehingga sumber daya manusia yang dipilih mampu melaksanakan pekerjaan itu dengan baik. Dari hasil analisis jabatan maka organisasi akan mampu menentukan karakteristik seperti apa yang harus dimiliki calon pegawai sebelum menduduki sebuah jabatan, yang outputnya berupa spesifikasi jabatan yang memuat siapa yang akan melakukan pekerjaan tersebut serta apa saja persyaratan yang dibutuhkan terutama kemampuan individu, dan deskripsi pekerjaan yang memuat tugas, fungsi, wewenang, dan tanggung jawab seorang pegawai.

Penerapan analisis jabatan menjadi salah satu kewajiban yang harus dilaksanakan oleh seluruh organisasi Perangkat Daerah. Hal ini bertujuan untuk mendapatkan hasil terbaik yang sesuai dengan prinsip manajemen sumber daya manusia yaitu prinsip the right man on the right place yang artinya untuk menempatkan orang yang tepat pada tempat yang tepat, sehingga dalam penempatan pegawai dalam pengisian formasi jabatan baik jabatan struktural, jabatan pelaksana dan jabatan fungsional harus berdasarkan analisis jabatan karena kemampuan dan kesesuaian seseorang dalam memahami tugas pokok dan fungsi jabatan dengan penerapan prinsip analisis jabatan tersebutakan berpengaruh terhadap kinerja dan pencapaian tujuan organisasi. Sedangkan formasi jabatan adalah jumlah dan susunan jabatan Pegawai Aparatur Sipil Negara yang bertanggung jawab melaksanakan kegiatan pelayanan publik serta administrasi pemerintahan dan pembangunan yang diperlukan suatu satuan organisasi dan ditetapkan dalam suatu formasi untuk jangka waktu tertentu berdasarkan jenis, sifat dan beban kerja yang harus dilaksanakan dengan tujuan agar unit organisasi itu mampu melaksanakan tugasnya secara berdayaguna, berhasil guna dan berkelangsungan.

Penempatan pegawai dalam pengisian formasi jabatan pelaksana pada umumnya tidak melalui seleksi pegawai dalam pengisian formasi jabatan pelaksana, sehingga selain timbulnya rasa ketidakadilan dan kesenjangan sosial juga

terjadinya tumpang tindih dan konflik antara pegawai yang satu dengan yang lainnya seringkali melakukan pekerjaan yang sama walaupun mereka berada dalam bidang keahlian yang berbeda. Kondisi ini dapat mengakibatkan konflik, terutama dalam pertanggungjawaban atas pekerjaan yang membawa dampak dalam pencapaian tujuan organisasi. Selain mengakibatkan konflik, hal tersebut dapat mengganggu stabilitas berjalannya proses pelaksanaan pelayanan pada setiap perangkat daerah.

Pemerintah Provinsi DKI Jakarta pada Tahun 2014 telah menerapkan pemberian Tunjangan kepada para Pegawai Negeri Sipil (PNS) dengan sebutan Tunjangan Kinerja Daerah (TKD). Batas maksimal nominal TKD yang diterima didasarkan pada peringkat jabatan masing-masing. Akan tetapi nominal TKD yang diterima oleh PNS tersebut bergantung dengan tingkat kinerja PNS tersebut. Penempatan pegawai di Pemerintah Provinsi DKI Jakarta, terutama pada jabatan pelaksana belum seluruh- nya memperhatikan dan mempertimbangkan hasil analisa jabatan, analisa beban kerja, formasi jabatan dan standar kompetensi jabatan. Hal tersebut terjadi dikarenakan penempatan pegawai khususnya pelaksana, adalah kewenangan bagi masing masing kepala Satuan Kerja Perangkat Daerah (SKPD). Berikut disampaikan jumlah Pegawai Negeri Sipil (PNS) di lingkungan Pemerintah Provinsi DKI Jakarta :

Tabel 1. Data Pegawai Pemprov DKI Jakarta

\begin{tabular}{|c|l|c|c|}
\hline No & Jabatan & $\begin{array}{c}\text { Jumlah } \\
\text { Pegawai }\end{array}$ & \% \\
\hline 1 & Fungsional & 28.926 & 43,41 \\
\hline 2 & Struktural & 4.824 & 7,24 \\
\hline 3 & Staf & 32.877 & 49,34 \\
\hline \multicolumn{2}{|c|}{ JUMLAH } & $\mathbf{6 6 . 6 2 7}$ & \\
\hline
\end{tabular}

Sumber : BKD Provinsi DKI Jakarta, per Agustus 2018

Penelitian yang berkaitan dengan penempatan pegawai telah banyak dilakukan, namun banyak penelitian difokuskan kepada keterkaitan antara rekrutmen pegawai dan latar belakang pegawai dengan penempatan pegawai. Tetapi penelitian ini menggambarkan pentingnya analisa jabatan, formasi jabatan dan standar kompetensi jabatan dalam penempatan pegawai pada Pemerintah Provinsi DKI Jakarta. Dengan asumi bahwa penelitian ini dapat menjadi salah satu acuan dalam pembuatan kebijakan terkait dengan penempatan pegawai di lingkungan Pemerintah Provinsi DKI Jakarta.

Melalui penelitian ini diharapkan dapat mengetahui bagaimana persepsi pegawai terhadap pelaksanaan penempatan pegawai pada instansi 
pemerintah daerah terutama di lingkungan Pemerintah Provinsi DKI Jakarta.

\section{METODE}

Penelitian ini dilakukan dengan menggunakan metode penelitian deskriptif kualititatif. Menurut Sugiyono dalam Jatmiko (2019), menjelaskan bahwa metode penelitian pada dasarnya merupakan cara ilmiah untuk mendapatkan data dengan tujuan dan kegunaan tertentu. Adapun pengertian deskriptif menurut Sugiyono dalam (Jatmiko, 2019) adalah penelitian yang diarahkan untuk mengetahui nilai variable mandiri, baik satu variable atau lebih (independen) tanpa membuat perbandingan atau menghubungkan variable satu dengan variable yang lain.

Sedangkan pengertian kualitatif menurut Bogdan dan Taylor dalam Jatmiko (2019) merupakan metode penelitian kulitatif adalah prosedur penelitian yang menghasilkan data deskriptif berupa kata-kata tertulis atau ketepatan. Hasil dari evaluasi akan dapat memberikan solusi dari permasalahan yang timbul sehingga dapat dijadikan perbaikan dalam proses penempatan pegawai pada instansi pemerintah.

\section{Lokasi, Subjek dan Waktu Penelitian}

Penelitian ini dilakukan pada Pemerintah Provinsi DKI Jakarta. Penelitian ini menggunakan subjek penelitian adalah pegawai negeri sipil yang bekerja di lingkungan Pemerintah Provinsi DKI Jakarta. Penelitian ini dilakukan pada bulan Agustus sampai dengan September 2018

\section{Teknik Pengambilan Data}

Teknik pengambilan data yang digunakan dalam penelitian ini adalah menggunakan kuisioner sederhana yang disebarkan melalui media sosial (https://bit.ly/AnjabABKSK.com). Kuisioner yang terkumpul dilakukan pengolahan data sederhana untuk mengetahui hasilnya.

\section{HASIL DAN PEMBAHASAN}

Reformasi birokrasi pada hakikatnya merupakan upaya untuk melakukan pembaharuan dan perubahan mendasar terhadap sistem penyelenggaraan pemerintahan terutama menyangkut aspek-aspek kelembagaan (organisasi), ketatalaksanaan (business prosess) dan sumber daya manusia aparatur dan lain sebagainya. Hal ini terlihat dari adanya peraturan-peraturan dan tindak lanjut untuk pelaksanaan reformasi birokrasi pada setiap instansi pemerintah. Reformasi Birokrasi di Indonesia khususnya di lingkungan Pemerintah Provinsi DKI Jakarta telah diterapkan dengan cukup baik. Pemerintah Provinsi DKI Jakarta dalam menindaklanjuti pelaksanaan Reformasi Birokrasi telah menerbitkan Peraturan Gubernur Nomor 156 Tahun 2016 tentang Road Map Reformasi Birokrasi Tahun 2015 - 2017.

Berdasarkan Peraturan Gubernur Nomor 156 Tahun2016 tentang Road Map Reformasi Birokrasi 2015 - 2019 diketahui bahwa kegiatan strategis yang telah dilakukan Pemerintah Provinsi DKI Jakarta dalam upaya untuk mewujudkan birokrasi bersih dan efisien, antara lain:

1. Restrukturisasi organisasi;

2. Penyusunan peringkat jabatan;

3. Penempatan pegawai dalam jabatan pelaksana;

4. Pemetaan pegawai;

5. Penyusunan standar kompetensi jabatan;

6. Penyusunan analisa jabatan dan analisabeban kerja

7. Penetapan pemberian Tunjangan Kinerja Daerah (TKD) berbasis kinerja;

TKD pada setiap PNS di lingkungan Pemerintah Provinsi DKI Jakarta berdasarkan Peraturan Gubernur Nomor 409 Tahun 2017 tentang Tunjangan Kinerja Daerah dijelaskan bahwa TKD diberikan kepada setiap PNS yang menduduki suatu jabatan. Jabatan tersebut terdiri dari jabatan pelaksana, jabatan administrasi dan jabatan pimpinan tinggi, dengan nominal batas maksimal TKD berdasarkan peringkat jabatan pada masingmasing jabatan tersebut.

Penyusunan peringkat jabatan didasarkan pada hasil analisa jabatan dan analisa beban kerja yang telah disusun. Serta setiap jabatan didasari dengan adanya standar kompetensi jabatan. Manfaat adanya analisa jabatan dan analisa beban kerja pada setiap instansi adalah untuk menghasilkan adanya formasi jabatan dan peta jabatan. Dengan adanya dokumen-dokumen tersebut diharapkan akan memudahkan dan membantu setiap instansi terkait dengan penempatan pegawai.

Hasil penelitian ini lebih ditekankan kepada kesesuaian antara dokumen analisa jabatan, analisa beban kerja dan formasi jabatan serta standar kompetensi jabatan dengan penempatan pegawai di lingkungan Pemerintah Provinsi DKI Jakarta. Selain pada hal tersebut penelitian ini akan meetahui keberadaan, keterlibatan pegawai 
dalam menyusun dokumen-dokumen tersebut. Berdasarkan hasil kuisioner yang telah di lakukan kepada 59 responden, dapat disampaikan hal-hal sebagai berikut :

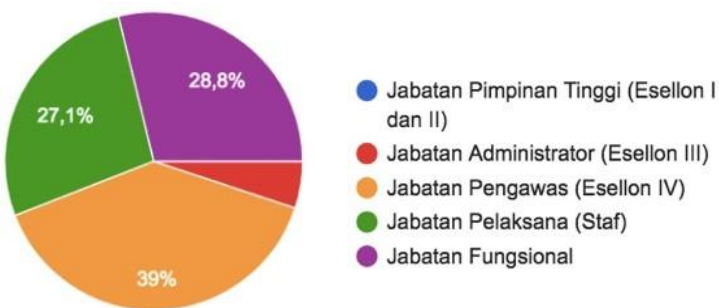

Gambar 2. Sebaran Respoden yang Mengisi Kuisioner (data diolah)

Berdasarkan gambar 2 diatas diketahui bahwa dari 59 responden pada penelitian ini dapat terlihat bahwa terbagi kedalam beberapa jenis jabatan yang sesuai dengan ketentuan dan peraturan yang berlaku, yaitu :

1. Jabatan Pimpinan Tinggi sebanyak 0orang,

2. Jabatan Administrator sebanyak 3 orang $(5,1 \%)$

3. Jabatan Pengawas sebanyak 23 orang(39\%)

4. Jabatan Pelaksana sebanyak 16 orang $(27,1 \%)$

5. Jabatan Fungsional sebanyak 17 orang $(28,8 \%)$

Berdasarkan hal tersebut dapat diketahui bahwa sebaran responden pada penelitian ini tidak terbatas pada salah satu jabatan tertentu saja melainkan tersebar dan berasal dari berbagai Satuan Kerja Perangkat Daerah (SKPD).

Keberadaan Dokumen Analisa Jabatan Dan Analisa Beban Kerja, Formasi Jabatan serta Standar Kompetensi

Tabel 2. Keberadaan Dokumen

\begin{tabular}{|c|l|c|c|}
\hline \multirow{2}{*}{ No } & \multicolumn{2}{|c|}{ Dokumen } & \multicolumn{2}{|c|}{ Keberadaan } \\
\cline { 3 - 4 } & & Ya & Tidak \\
\hline 1 & $\begin{array}{l}\text { Analisa Jabatan } \\
\text { dan ABK }\end{array}$ & 55 & 4 \\
\hline 2 & Formasi Jabatan & 57 & 2 \\
\hline 3 & $\begin{array}{l}\text { Standar Komptensi } \\
\text { Jabatan }\end{array}$ & 47 & 12 \\
\hline
\end{tabular}

Sumber : data diolah

Dari tabel 2 diatas dapat dijelaskan bahwa secara rata-rata responden menyebutkan bahwa mereka telah memiliki dokumen-dokumen analisa jabatan dan analisa beban kerja, formasi jabatan dan dokumen standar kompetensi jabatan. Akan tetapi masih terdapat beberapa responden yang tidak mengetahui adanya dokumen analisa jabatan dan analisa beban kerja, formasi jabatan dan dokumen standar kompetensi jabatan.

Hal ini menandakan bahwa ketidaktahuan adanya dokumen-dokumen tersebut, dikhawatirkan responden tersebut tidak mengetahui terkait dengan analisa jabatan dan analisa beban kerja, formasi jabatan dan standar kompetensi jabatan dari jabatan responden saat ini. Apabila responden tidak mengetahuinya, dimungkinkan akan mengurangi kinerja dari responden tersebut serta kinerja instansi/ organisasi.

Keterlibatan Pegawai terhadap Penyusunan Dokumen Analisa Jabatan Dan Analisa Beban Kerja, Formasi Jabatan serta Standar Kompetensi

Berdasarkan keberadaa dokumen diatas, penelitian ini juga mencari tahu keterlibatan responden terhadap penyusunan dokumendokumen tersebut, sebagimana terlihat dalam tabel dibawah ini:

Tabel 3. Keterlibatan Penyusunan Dokumen

\begin{tabular}{|c|l|c|c|}
\hline \multirow{2}{*}{ No } & \multirow{2}{*}{ Dokumen } & \multicolumn{2}{|c|}{ Keterlibatan } \\
\cline { 3 - 4 } & & Ya & Tidak \\
\hline 1 & $\begin{array}{l}\text { Analisa Jabatan } \\
\text { dan ABK }\end{array}$ & 31 & 28 \\
\hline 2 & Formasi Jabatan & 23 & 36 \\
\hline 3 & $\begin{array}{l}\text { Standar } \\
\text { Komptensi } \\
\text { Jabatan }\end{array}$ & 17 & 42 \\
\hline
\end{tabular}

Sumber : data diolah

Tabel 3 diatas dapat dijelaskan bahwa pegawai tidak terlalu terlibat dalam penyusunan dokumen-dokumen analisa jabatan dan analisa beban kerja, formasi jabatan dan dokumen standar kompetensi jabatan. Hal ini bertentangan dengan peraturan struktur organisasi dan tata kerja masing-maisng SKPD yang menyatakan bahwa masing-masing jabatan mempunyai tugas salah satunya adalah penyusunan analisa jabatan dan analisa beban kerja. 


\section{Kesesuaian Penempatan Pegawai dengan Kebutuhan Organisasi}

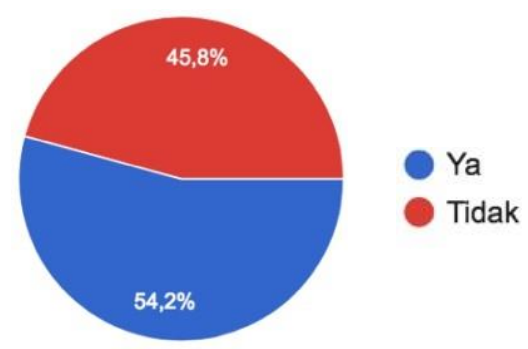

Gambar 3. Kesesuaian Penempatan Pegawai (data diolah)

Berdasarkan gambar 3 diatas diketahui bahwa dari hasil penelitian terungkap bahwa sebanyak 27 atau 45,8\% responden manyatakan bahwa penempatan pegawai yang dilaksanakan pada instansinya masih tidak sesuai dengan kebutuhan instansi. Dan sebanyak 32 atau 54,2\% responden menyatakan bahwa penempatan pegawai sudah sesuai dengan kebutuhan organisasi. Undang-undang Nomor 5 Tahun 2014 tentang Aparatur Sipil Negara diketahui bahwa penempatan pegawai berdasarkan kompetensi, kualifikasi dan kinerja dari pegawai tersebut. Berdasarkan penjelasan diatas cukup mengkhawatirkan karena ketidaksesuaian penempatan pegawai dapat mengakibatkan tidak berjalan lancarnya pelaksanaan tugas pada jabatan tersebut.

\section{Kesenjangan Penempatan Pegawai}

Kekhawatiran tersebut, terlihat dari hasil penelitian bahwa sebanyak 41 atau $69,5 \%$ responden menyatakan bahwa terdapat kesenjangan dalam penempatan pegawai pada instansinya. Dan sebanyak 18 atau $30,5 \%$ responden menyatakan bahwa penempatan pegawai pada instansinya tidak terdapat kesenjangan. Hal tersebut sebagaimana tertera pada diagram dibawah ini :

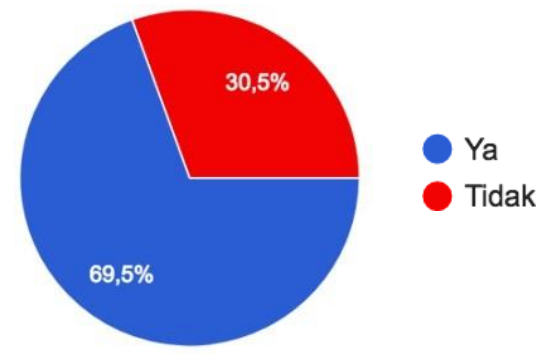

Gambar 4. Kesenjangan Penempatan Pegawai (data diolah)
Berdasarkan gambar 4 diatas diketahui bahwa, lebih banyak responden menyatakan bahwa masih terdapat kesenjangan penempatan pegawai. Apabila dikaitkan dengan gambar sebelumnya (Gambar 3. Kesesuaian Penempatan Pegawai), maka dapat dijelaskan bahwa responden yang menyatakan sudah ada kesesuaian penempatan pegawai, menyatakan bahwa masih terdapat kesenjangan penempatan pegawai. Dengan demikian dapat diartikan bahwa kesesuaian penempatan pegawai berdasarkan kebutuhan instansi/organisasi tidak menjamin tidak adanya kesenjangan dalam penempatan pegawai. Hal tersebut, dapat disimpulkan bahwa penempatan pegawai yang baik bukan hanya berasal dari adanya kebutuhan instansi melainkan faktor - faktor yang lainnya.

\section{Pentingnya Dokumen Analisa Jabatan Dan Analisa Beban Kerja, Formasi Jabatan serta Standar Kompetensi pada Instansi Pemerintah Daerah}

Hasil penelitian ini mengetahui seberapa pentingnya penyusunan dokumen analisa jabatan dan analisa beban kerja, formasi Jabatan serta standar kompetensi pada setiap instansi pemerintah/ khususnya di pemerintah daerah, sebagaimana dapat dilihat pada gambar dibawah ini :

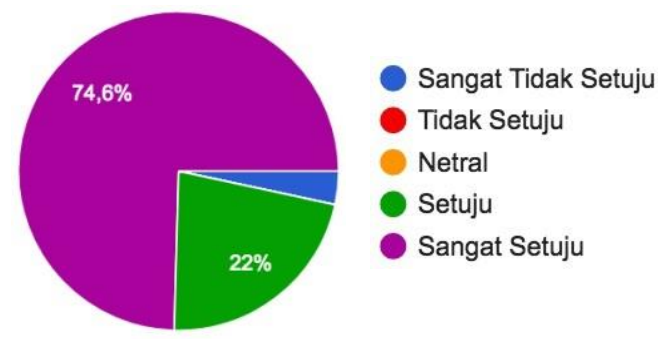

Gambar 5. Pentingnya Penyusunan Dokumen (data diolah)

Berdasarkan gambar 5 diatas diketahui bahwa sebanyak 44 atau $74,6 \%$ responden menyatakan sangat setuju dan sebanyak 13 atau $22 \%$ responden menyakatan setuju bahwa dokumen analisa jabatan dan analisa beban kerja, formasi Jabatan serta standar kompetensi sangat penting dimiliki oleh Pemerintah Provinsi DKI Jakarta. Hal tersebut dapat dibuat kesimpulan bahwa pegawai di lingkungan Pemerintah Provinsi DKI Jakarta sependapat dengan peraturan perundang-undangan yang berlaku bahwa setiap instansi pemerintah wajib 
menyusun dokumen analisa jabatan dan analisa beban kerja, formasi Jabatan serta standar kompetensi jabatan.

Dengan adanya dokumen analisa jabatan dan analisa beban kerja, formasi Jabatan serta standar kompetensi jabatan diharapkan dapat meningkatkan keberhasilan instansi tersebut dalam menggapai rencana pembangunannya. Hal tersebut dikarenakan dokumen analisa jabatan dan analisa beban kerja, formasi Jabatan serta standar kompetensi juga dapat menjadi acuan dalam penempatan pegawai pada setiap jabatan yang ada.

Dokumen Analisa Jabatan Dan Analisa Beban Kerja, Formasi Jabatan serta Standar Kompetensi digunakan sebagai dasar Penempatan Pegawai

Berkaitan dengan dokumen analisa jabatan dan analisa beban kerja, formasi Jabatan serta standar kompetensi dapat digunakan sebagai dasar penempatan pegawai pada Pemerintah Provinsi DKI Jakarta, responden juga menyatakan hal yang sama. Yaitu sebanyak 19 atau $32,2 \%$ responden sangat setuju dan 25 atau $42,4 \%$ responden setuju bahwa penempatan pegawai di lingkungan Pemerintah Provinsi DKI Jakarta pada saat ini sudah berdasarkan dokumen analisa jabatan dan analisa beban kerja, formasi Jabatan serta standar kompetensi yang ada. Hal tersebut sebagaimana dapat dilihat pada gambar dibawah ini :

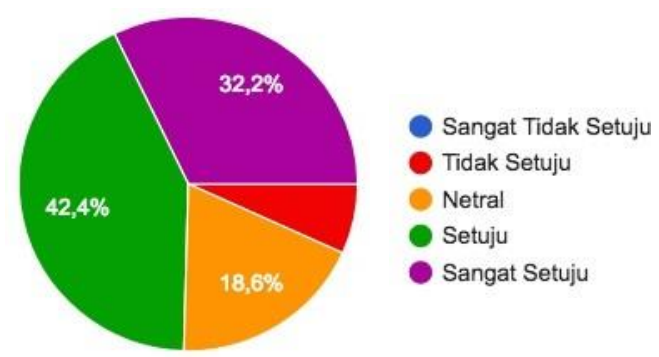

Gambar 6. Penggunaan Dokumen Sebagai Dasar Penempatan (data diolah)

Berdasarkan gambar 6 diatas diketahui bahwa terdapat hal yang menarik atas hasil penelitian ini, bahwa berdasarkan hal tersebut terdapat sebanyak 44 atau $64,6 \%$ responden sependapat setuju dan sangat setuju bahwa penempatan pegawai di lingkungan Pemerintah Provinsi DKI Jakarta pada saat ini sudah berdasarkan dokumen analisa jabatan dan analisa beban kerja, formasi Jabatan serta standar kompetensi. Akan tetapi pada hasil penelitian (Gambar 3. Kesesuaian Penempatan Jabatan), diketahui bahwa sebanyak 32 atau $54,2 \%$ responden manyatakan bahwa penempatan pegawai yang dilaksanakan pada instansinya masih sesuai dengan kebutuhan instansi/organisasi. Dan pada hasil penelitian (Gambar 4. Kesenjangan Penempatan Pegawai) diketahui bahwa sebanyak 41 atau $69,5 \%$ responden menyatakan bahwa masih terdapat kesenjangan dalam penempatan pegawai.

Berdasarkan data diatas dapat dijelaskan bahwa penempatan pegawai pada Pemerintah Provinsi DKI Jakarta saat ini telah sesuai dengan kebutuhan dan juga tetap memperhatikan dokumen analisa jabatan dan analisa beban kerja, formasi Jabatan serta standar kompetensi. Akan tetapi walaupun pelaksanaan penempatan pegawai sudah sesuai dengan kebutuhan dan juga tetap memperhatikan dokumen analisa jabatan dan analisa beban kerja, formasi Jabatan serta standar kompetensi dalam penempatan pegawai, masih terdapat banyak kesenjangan dalam penempatan pegawai tersebut. Dapat diartikan bahwa masih adanya ketidaksesuaian dokumen analisa jabatan dan analisa beban kerja, formasi Jabatan serta standar kompetensi dengan kondisi yang jabatan dibutuhkan oleh instansi.

\section{Pentingnya Kesesuaian Penempatan Pegawai dengan Dokumen Analisa Jabatan Dan Analisa Beban Kerja, Formasi Jabatan serta Standar Kompetensi}

Hasil penelitian lainnya yang dilakukan pada penelitian ini adalah perihal dengan pentingnya kesesuaian penempatan pegawai dengan dokumen analisa jabatan dan analisa beban kerja, formasi jabatan serta standar kompetensi jabatan seperti dibawah ini :

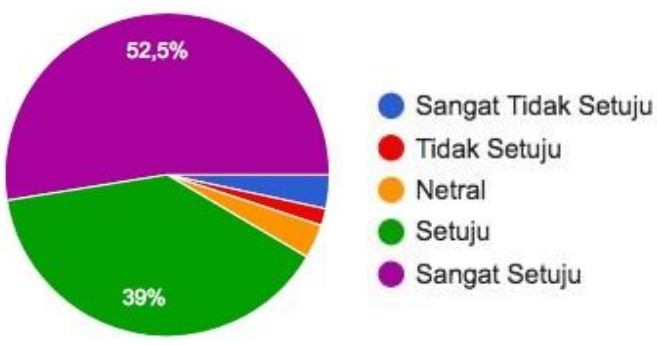

Gambar 7. Pentingnya Kesesuaian Penempatan terhadap Dokumen (data diolah)

Berdasarkan gambar 7 diatas diketahui bahwa sebanyak 31 atau 52,5 responden menyatakan sangat setuju dan sebanyak 23 atau 39\% 
responden menyakatan setuju bahwa kesesuaian penempatan pegawai dengan dokumen analisa jabatan dan analisa beban kerja, formasi jabatan dan dokumen standar kompetensi jabatan merupakan suatu yang sangat penting. Hal tersebut dapat diartikan bahwa responden sangat sadar dan sepakat dengan peraturan perundang undangan yang menyatakan bahwa penempatan pegawai harus sesuai dengan kompetensi/ kualifikasi dari pegawai tersebut.

\section{Pentingnya Penempatan Pegawai terhadap Keberhasilan Instansi}

Selain beberapa hasil diatas, penelitian ini juga melihat pendapat dari responden terkait dengan pentingnya penempatan pegawaiterhadap keberhasilan instansi/ organisasi. Hal ini dapat dilihat sebagaimana gambar dibawah ini :

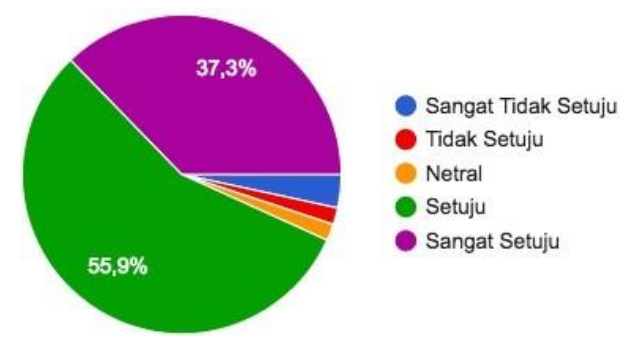

Gambar 8. Penempatan Pegawai terhadap Keberhasilan Organisasi (data diolah)

Berdasarkan gambar 8 diatas diketahui bahwa, dapat dijelaskan bahwa sebanyak 22 atau $37,3 \%$ responden menyatakan sangat setuju dan sebanyak 33 atau 55,9\% responden menyatakan setuju bahwa penempatan pegawai merupakan bagian penting dari keberhasilan instansi/ organisasi. Adapun responden yang menyatakan tidak setuju dan sangat tidak setuju adalah sebanyak 3 atau 5,08\% responden. Dengan demikian terdapat faktor-faktor lain menurut responden yang merupakan keberhasilan dari suatu instansi/ organisasi.

\section{PENUTUP}

\section{Simpulan}

Dari hasil penelitian ini, dapat disimpulkan bahwa pelaksanaan 8 (delapan) area reformasi birokrasi di Indonesia khususnya di lingkungan Pemerintah Provinsi DKI Jakarta terutama area sumber daya manusia terkait dengan penempatan pegawai telah dilakukan dengan karena adanya kebutuhan instansi/organisasi serta pelaksanaan penempatan Pegawai Negeri Sipil (PNS) yang mempertimbangkan hasil analisa jabatan dan analisa beban kerja, formasi jabatan dan standar kompetensi dari jabatan tersebut. Akan tetapi, berdasarkan persepsi pegawai, dalam penetapan pegawai di lingkungan Pemerintah Provinsi DKI Jakarta masih terdapat kesenjangan.

Dengan mempertimbangkan hasil analisa jabatan dan analisa beban kerja, formasi jabatan dan standar kompetensi dari jabatan tersebut, diharapkan akan menghasilkan pemangkujabatan yang dapat menghasilkan kinerja individu serta kinerja instansi/ organisasi yang sesuai dengan apa yang telah direncanakan. Selain dengan hal tersebut, penyusunan dokumen analisa jabatan dan analisa beban kerja, formasi jabatan dan standar kompetensi dari jabatan juga harus dilaksanakan oleh instansi masing-masing dengan memperhatikan kaidah-kaidah atau ketentuanketentuan yang berlaku.

\section{Saran}

Saran disusun berdasarkan temuan penelitian yang telah dibahas. Saran dapat mengacu pada tindakan praktis, pengembangan teori baru, dan/atau penelitian lanjutan antara lain :

1. Perlu adanya kebijakan yang berguna sebagai pedoman dalam pelaksanaan penempatan pegawai, baik penempatan pegawai pada jabatan pelaksana, pengawas, fungsional maupun pimpinan tinggi, sesuai kebutuhan dan ketentuan yang berlaku;

2. Perlu adanya monitoring dan evaluasi yang lebih mendalam lagi terkait dengan penempatan pegawai, terutama pada penempatan pegawai dengan jabatan pelaksana;

3. Perlu adanya kajian atau penelitian yang lebih mendalam lagi terkait dengan pengaruh penempatan pegawai terhadap kinerja individu maupun instansi/ organisasi;

4. Pelaksanana penempatan pegawai terutama pada jabatan pelaksana, harus tetap mempertimbangkan dokumen analisa jabatan, analisa beban kerja, formasi jabatan dan standar kompetensi dari suatu jabatan;

5. Perlu adanya program pengembangan kompetensi sumber daya manusia yang terintegrasi secara baik, guna peningkatan kualitas dan kesesuaian kompetensi sumber daya manusia dengan kualifikasi jabatan;

6. Seluruh pihak terkait harus ikut terlibat dalam penyusunan dokumen analisa jabatan, analisa beban kerja, formasi jabatan dan standar kompetensi dari suatu jabatan. Dan setelahnya 
perlu ada uji publik maupun sosialisasikepada seluruh stakeholder.

\section{DAFTAR PUSTAKA}

Febriani, W. M. (2017). Penempatan Kerja Pegawai Berdasarkan Latar Belakang Pendidikan di Kabupaten Kutai Timur. eJournal Pemerintahan Integratif.

Hadinata, M. D. (2012). Analisis Penempatan Pegawai Pada Badan Kepegawaian Daerah Kabupaten Indragiri Hilir. Jatmiko, A. (2019). Evaluasi Implementasi Layanan Pertanahan Mandiri Tingkat Desa Berbasis On-Line System di Provinsi Nusa Tenggara Barat. Jurnal Kewidyaiswaraan

Kementerian Pendayagunaan Aparatur Negara dan Reformasi Birokrasi. Peraturan Menteri Negara Pendayagunaan Aparatur Negara dan Reformasi Birokrasi Nomor 9 tahun 2011 Pedoman Penyusunan Road Map Reformasi Birokrasi Kementerian/ Lembaga dan Pemerintah Daerah;

Kementerian Pendayagunaan Aparatur Negara dan Reformasi Birokrasi. Peraturan Menteri Negara Pendayagunaan Aparatur Negara dan Reformasi Birokrasi Nomor 33 Tahun 2011 tentang Pedoman Analisis Jabatan;

Lumataw, Y. L., Massie, R. G., \& Umboh, J. M. (2014). Gambaran Analisis Jabatan, Rekrutmen, Seleksi Penempatan dan Promosi Pegawai pada Jabatan
Struktural Dinas Kesehatan Kota Gorontalo Tahun 2014. JIKMU.

Oktaria, A. (2013). Hubungan Penempatan Pegawai dengan Kinerja Pegawai di Kantor Dinas Sosial Provinsi Sumatera Barat. Jurnal Administrasi Pendidikan;

Pemerintah Provinsi Daerah Khusus Ibukota Jakarta. Peraturan Gubernur Nomor 156 Tahun 2016 tentang Road Map Reformasi Birokrasi 2015 - 2019;

Pemerintah Provinsi Daerah Khusus Ibukota Jakarta. Peraturan Gubernur Nomor 409 Tahun 2017 tentang Tunjangan Kinerja Daerah;

Pemerintah Republik Indonesia. Peraturan Pemerintah Nomor 11 Tahun 2017 tentang Manajemen Pegawai Negeri Sipil;

Putri, A. D., Entang, A., \& Candradewini. (2017). Penempatan Pegawai di Badan Kepegawaian Daerah Kota Bandar Lampung. Jurnal Administrasi Negara.

Republik Indonesia. Undang - Undang Nomor 5 Tahun 2014 tentang Aparatur Sipil Negara;

Sugiat. (2013). Peranan Badan Kepegawaian Daerah Dalam Pelaksanaan Rekruitmen dan Penempatan Pegawai Negeri Sipil di Lingkungan Pemerintah Kota Samarinda. eJournal Ilmu Pemerintahan;

Sukarno, A. (2014). Analisis Penempatan Pegawai Pada Pusat Kajian dan Pendidikan dan Pelatihan Aparatur II Lembaga Administrasi Negara Makasar. Jurnal Administrasi Publik; 